Este ensaio, assim como o de

Norman Friedman, "O Ponto de

Vista na Ficção" |Revista USP, ne

53), foram indicados para publi-

cação pelo Programa de Pós-Gra-

duação em Teoria Literária e Litera-

tura Comparada da FFLCH-USP.
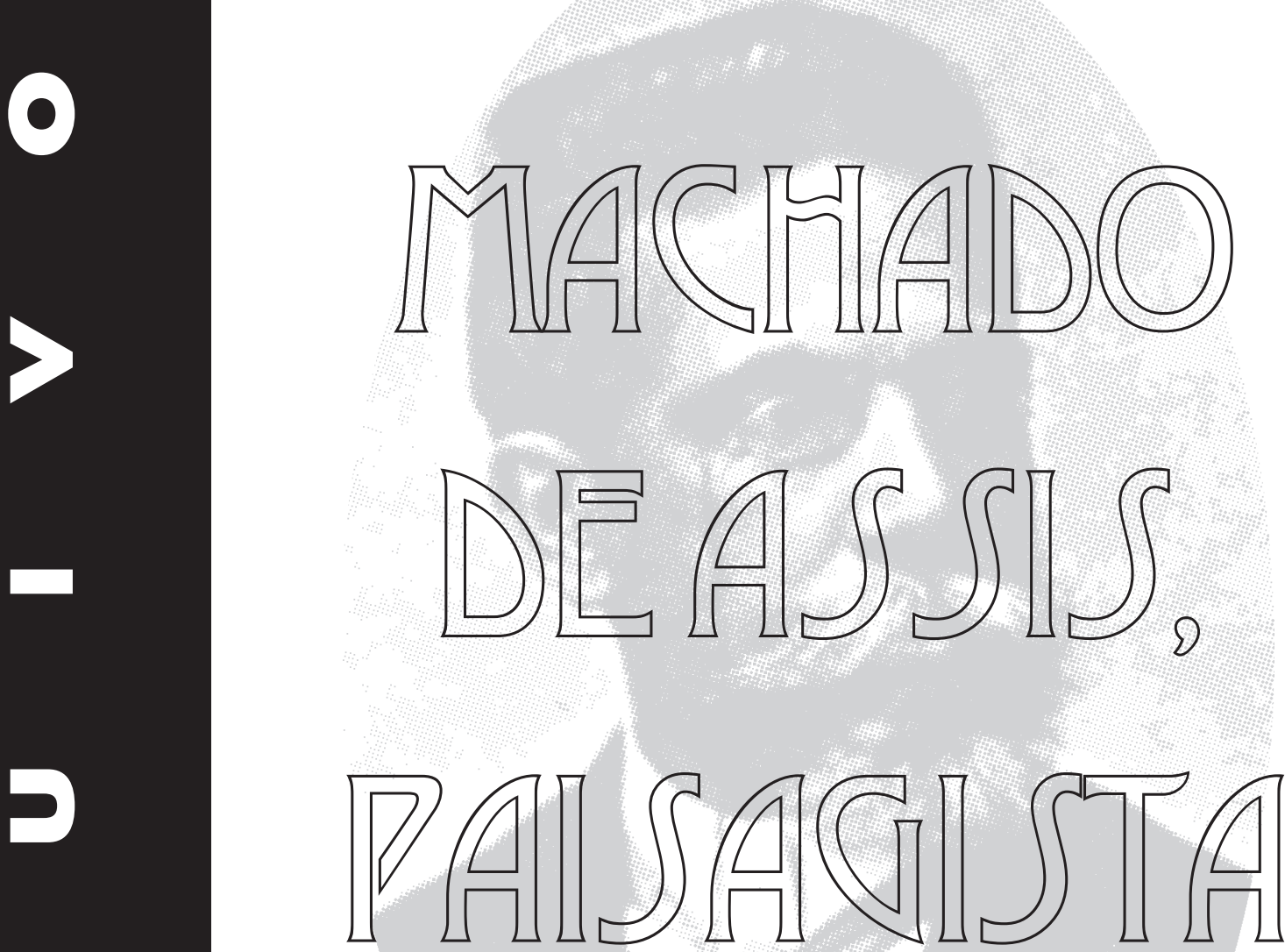

$\boldsymbol{\sigma}$

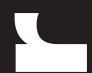

\title{
ROGER BASTIDE
}

Apresentação de Joaquim Alves de Aguiar

O presente estudo apareceu na Re- critos. Roger Bastide teria, de acordo vista do Brasil, em novembro de 1940. com o crítico, desfeito o equívoco de anSua importância na fortuna crítica tigas afirmaçôes segundo as quaiso nosmachadiana foi apontada por Anto- so maiorescritornāo teria sentido a "nanio Candido, há mais de trinta anos, tureza deseupais". O sociólogo francês, no seu admirável "Esquema de Macha- que lecionou na USP (viveu no Brasil do de Assis", publicado em Vários Es- entre os anos de 1938 e 1954), contra- 
riando o nativismo patriótico de velhos leitores, havia percebido que o autor de Dom Casmurro incorpora a paisagem brasileira "à filigrana da narrativa", tornando-a "elemento funcional da composição literária". Anos depois, Antonio Candido voltaria ao assunto, de maneira mais detida, nos seus Recortes: "Este ensaio, somado a outros do mesmo autor, bem como ao seu ensino e ao seu convívio, teve mui- ta influência em mim, coisa que custei a perceber. Quando o reli há tempos, depois de muitos anos, senti que foi uma das fontes de várias idéias que estão na base da minha concepção de literatura brasileira". Creio que bastam essas razóes para que "Machado de Assis, Paisagista” reapareça nesta seção da Revista USP, planejada para divulgar e facilitar o acesso a textos raros e importantes.

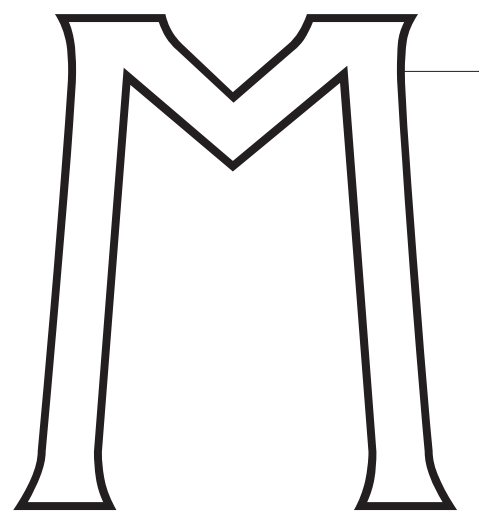

achado de Assis, pintor da natureza e paisagista, não serão palavras que se repelem? Não é a regra, mesmo entre os mais intransigentes admiradores de Machado, reconhecer-lhe na obra essa lacuna, a falta de descrições, a ausência do Brasil tropical? Não confessou ele mesmo essa limitação da sua arte quando fez um herói de um de seus romances, portavoz de seus próprios sentimentos, dizer: "nem marinha nem paisagem, não soube de nada...”, ou ainda: “eu não sei descrever nem pintar" (1)?

E entretanto?... Entretanto, reputo Machado de Assis um dos maiores paisagistas brasileiros, um dos que deram à arte da paisagem na literatura um impulso semelhante ao que se efetuou paralelamente na pintura, e que qualificarei, se me for permitido usar uma expressão "mallarmiana", de presença, mas presença quase alucinante, de uma ausência. É, pelo menos, o que desejaria demonstrar nestas breves páginas, procurando primeiro saber por que a paisagem parece ausente e, em seguida, por que ela é, todavia, terrivelmente presente. 
O gênero cultivado por Machado de Assis e seus processos técnicos, eis sem dúvida a principal razão que lhe impedia consagrar na sua obra longos trechos à descrição da natureza. É, com efeito, a lei de todos os gêneros curtos, como o conto, a novela, resumir o drama ao essencial, concentrar o interesse em vez de deixá-lo dispersar-se em pontos secundários, e é evidente que a paisagem só poderia desviar a atenção. As descrições podem, naturalmente, existir, mas desde que se reduzam a uma extensão da narrativa em que se enquadram. É o que fazia La Fontaine em suas fábulas: dois, três versos lhe bastavam para sugerir um quadro, evocar um recanto de água, verdura e sombra. É exatamente o que faz Machado de Assis: algumas linhas lhe chegam para pôr diante de nós uma doce paisagem marítima: "Divertia-se em olhar para as gaivotas, que faziam grandes giros no ar, ou pairavam em cima d'água, ou avoaçavam somente. O dia estava lindíssimo. Não era só um domingo cristão: era um imenso domingo universal" (2). Dir-me-ão talvez que essas estampas ligeiras, em três pinceladas, só sugerem paisagens banais, nada fixam do que é estrita e autenticamente brasileiro. A objeção é capciosa: peço um pouco de paciência, responderei ao estudar a reivindicação nativista em Machado de Assis. Por ora, fiquemos no exame de seus processos de escritor.

Quase todos os seus processos condenam as longas descrições: a conversa, que permite quando muito uma pausa de algumas linhas para evocar o jardim, a floresta, a praia luminosa; algumas linhas apenas, para não interromper o curso da conversa, para não perder-se o fio do diálogo; a narrativa: muitos contos são construídos sobre esse tema, uma personagem que conta uma história; ora, se observarmos alguém falando, não o veremos nunca entrecortar o monólogo de descrições; a descrição é uma invenção do estilo escrito, não pertence ao estilo verbal: Machado de Assis, querendo ser natural, respeita com toda a razão essa lei.
Assim a eliminação da paisagem foi imposta ao escritor pelas normas estéticas do gênero que pratica e pelos métodos que utiliza. A dificuldade, todavia, não está resolvida, mas apenas adiada; resta saber por que Machado de Assis escolheu esse gênero. Teria marcada predileção pelos seus processos? Não os adotou justamente por não possuir o sentimento da natureza? Por não saber pintar? Para evitar, com esse desvio, que ficasse patente a sua inferioridade em determinado domínio? Na realidade, tudo se prende a causas de ordem sociológica, no momento histórico em que compôs sua obra.

Gilberto Freyre assinalou claramente, em Sobrados e Mucambos, as transformações que se operaram durante o Império na estrutura social do Brasil e as repercussões dessas modificações na alma e na consciência dos homens dessa época: depois do isolamento nas casas-grandes, na solidão dos canaviais, cortado apenas pelas visitas de parentes, pela passagem de um hóspede a experiência da cidade, da comunhão, a descoberta de um novo prazer: a conversa. É evidente que a arte de Machado de Assis corresponde ao desabrochar dessa sociedade urbana, a esse instante de embriaguez após três séculos de patriarcalismo, de encerramento no círculo da família, a essa nova alegria de viver. Não é impunemente que a rua representa nos romances do nosso escritor um papel considerável: é que ela constitui o ponto de ligação das casas, une entre si as salas de visitas, significa o fim do isolamento colonial. Ora, a sociedade urbana cria forçosamente uma arte de diálogo e de análise psicológica; diálogo, por causa da importância preponderante que assumem os salões e as conversas, galantes ou de negócios; análise psicológica, porque esta é uma conversa que continua depois da outra, uma conversa que cada um tem de si para si, em que o eu se divide em várias personagens que porfiam, se criticam mutuamente, dialogam umas com as outras. A técnica de Machado de Assis não é uma burla para dissimular fraqueza na arte da descrição, mas um efeito, uma resultante quase fatal da vida carioca (3). 
É verdade que o primeiro momento da urbanização foi marcado pela eclosão da literatura romântica, istoé, uma literatura de glorificação da natureza brasileira. Mas é que a urbanização ainda não pudera fazer sentir todos os efeitos - o sobrado não será mais que o prolongamento do engenho, que a casa-grande transportada para a cidade, isolada no seu jardim, e o contato só conseguia fazer sentir não o que se ganhara, mas o que se perdera, intensificando assim a nostalgia da vida rural, da floresta selvagem ressoante de vozes de pássaros, da paz das palmeiras juncando a terra de suas sombras recortadas. Machado de Assis não pertence a esse primeiro período da urbanização, a esse instante romântico, em que o amor, em vez de ser diálogo, se torna logo, para corações que trazem ainda em si a herança da solidão, poesia pessoal, cantolírico. Pertence à fase naturalista, à nova geração que conseguiu adaptar-se ao novo habitat; e sabese que o que distingue a passagem de uma escola literária para outra é a crítica severa da primeira pela segunda. Ora, dando a primeira um lugar importante ao sentimento da natureza, não será a segunda levada a reagir contra essa proeminência?

Dois fatos parecem corroborar esta hipótese: a existência, em certos contos, de descrições irônicas, onde a paisagem é pretexto para troças, pelo encontro voluntário de epítetos banais: aurora de dedos de rosa, etc. e de "clichês" românticos que são destarte relegados aos mesmos museus de antigüidades, aos mesmos depósitos dos acessórios fora do uso. Há nisso ainda o desejo de mostrar que a descrição romântica é um processo fácil, de um sentimentalismo banal, ao alcance de qualquer um. Poesia de cozinheira! Não surpreendeu ele um dia a sua, que tinha "seus laivos de poesia entre a carne e a batata", a extasiar-se, diante da janela aberta, com as noites do Rio: “As ondas estão tão quietas! Tão pequenas! Parecem passarinhos. Que artista seria capaz de fazer assim... uma peça de chita?" (4).

Mas a sua crítica das descrições da natureza nem sempre assume esse aspecto amável e esse tom de humour. Faz-se áspera por vezes, deixando perceber um tremor de cólera. É que ela se prende também ao "nativismo" de Machado de Assis. Já se disse que ele não foi um escritor brasileiro: "Faltava-lhe... um sentimento... de amor à terra, à sua paisagem, à sua gente", diz Aurélio Buarque de Holanda, e Cassiano Ricardo acrescenta este qualificativo: "grande escritor brasileiro de espírito antibrasileiro" (5). Confesso que essas opiniões mexem um pouco comigo. $\mathrm{O}$ patriotismo de Machado de Assis foi ardente e ele celebrou em seus versos tanto a índia como a humilde mucama seduzida pelo senhor-moço, introduziu em suas Americanas termos tupis, procurou escrever à brasileira e não à portuguesa... Mas seu patriotismo soube, com razão, ver um perigo no gosto de seus predecessores pelas paisagens exóticas.

Quando, convidada a dar uma impressão sobre o Brasil, Sarah Bernhardt respondeu aos jornalistas: "Ce paysféerique", Machado de Assis se sentiu revoltado:

"O meu sentimento nativista... sempre se doeu desta adoração da natureza. Raro falam de nós mesmos: alguns mal, poucos bem. No que todos estão de acordo, é no 'pays féerique'. Pareceu-me sempre um modo de pisar o homem e suas obras. Quando me louvam a casaca, louvam-me antes a mim que ao alfaiate. Ao menos, é o sentimento com que fico; se não a fiz, mandei fazê-la. Mas eu não fiz, nem mandei fazer o céu e as montanhas, as matas e os rios. Já os achei prontos, e não nego que são admiráveis, mas há outras coisas que ver”.

Um dia mostrara a um estrangeiro de passagem a Igreja do Castelo e aquele, depois de haver relanceado os olhos pela velha capela, logo saiu, sem uma palavra, para contemplar o mar, o céu e a montanha: "Que natureza que vocês têm!" E certamente, acrescenta Machado de Assis, nossa baía é um magnífico espetáculo. Mas essa beleza já existia antes do aparecimento dos homens. O visitante queria excluir do Brasil a ação do homem, a vontade brasileira; só tinha a criação de Deus, suprimindo tudo o que lhe acrescentara o povo
4 Crônicas, 3vol., p. 47.

5 Aurélio Buarque de Holanda Revista do Brasil, II, 13, p. 55 Cassiano Ricardo, Marcho para Oeste, t. II, pp. 274-5 
6 A Semana (1892-97). p. 35 A. Pujol observou bem esse nativismo machadiano e cita outro trecho eloqüente, aquele m que reclama uma literatura brasileira contra as influências

7 A Semana, t. XXIV, p. 432 européias: p. 268

da terra: ora, é nessa adição que melhor se manifesta a mistura das raças, a estrutura peculiar do país, o desejo de fazer alguma coisa de novo, em suma, a originalidade brasileira (6).

É preciso lembrar que pintar a natureza brasileira no que ela tem de mais tropical, de mais antieuropeu, é de um nativismo ilógico. Porque, quer queira quer não, o artista se coloca, para isso, exatamente no mesmo pé que o estrangeiro recém-chegado: quer dar uma sensação de exotismo. Para poder elogiar o que a paisagem carioca tem de original, é preciso compará-la mentalmente com outras, e, logo, adotar, provisoriamente pelo menos, uma alma européia.

A história literária o confirma. Oromantismo, que tanto contribuiria para a descrição lírica, foi dominado pela influência do romantismo francês, de Lamartine e Hugo particularmente. E o exotismo de suas paisagens reflete largamente o gosto do exotismo desses poetas de além-Atlântico.
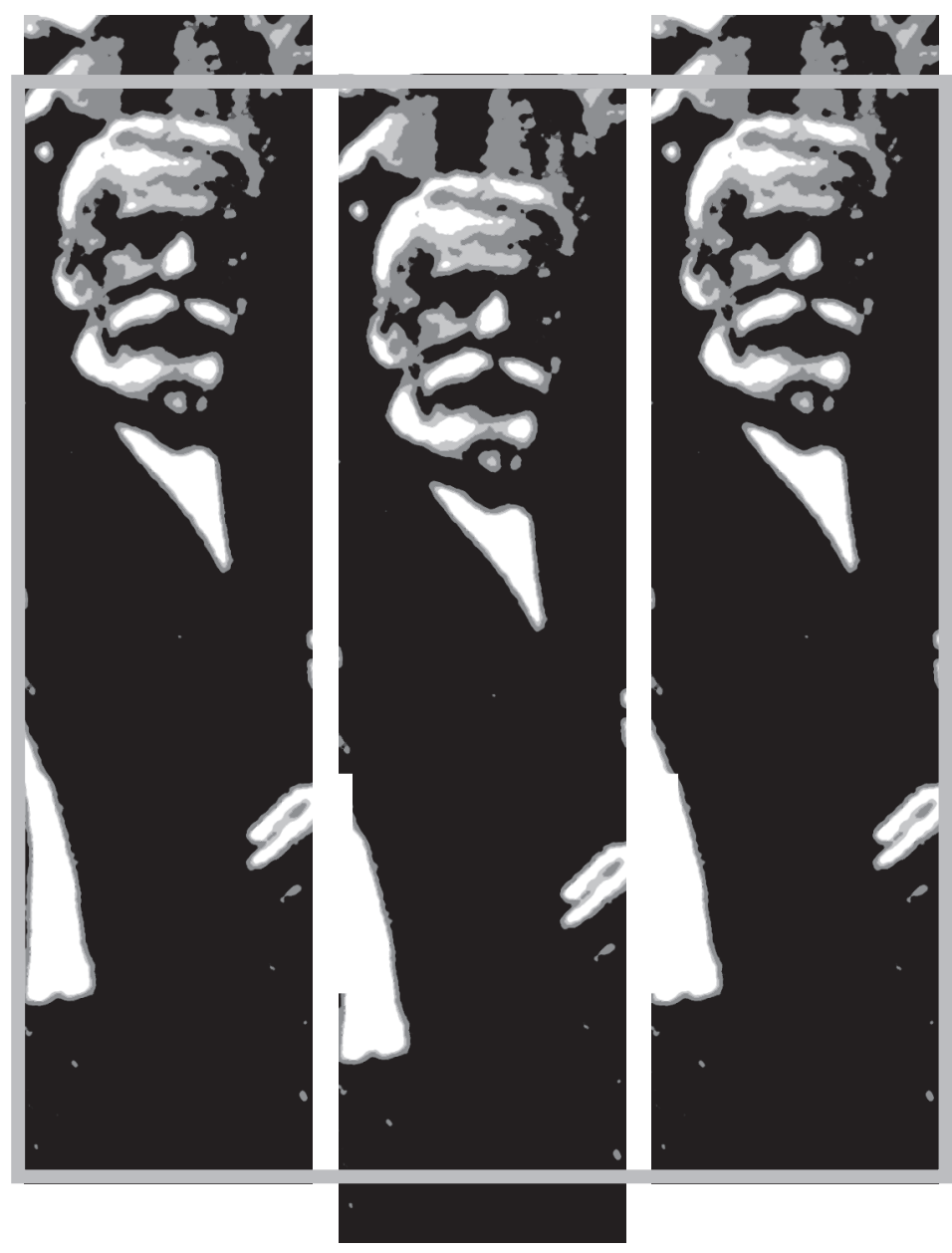

Mas o que se compreende num europeu ávido de sensações novas não corresponde ao que deve ser a visão de um autóctone, habituado desde cedo a um certo tipo de natureza. Outro fato ainda mais significativo é que a literatura modernista, porque começou em São Paulo, grande centro de imigrantes, encerra uma espécie de secreto desespero a manifestar-se na busca do " $\mathrm{ti}$ picamente brasileiro", como se pretendesse o nativo libertar-se da alma do imigrante que, por contágio, se vai infiltrando na sua; mas justamente só quem traz em si um pouco de imigrante é que consegue descobrir esse "tipicamente brasileiro", no curso do diálogo que se abre no espírito dividido contra si mesmo, entre o brasileiro e o recém-desembarcado da Europa.

Machado de Assis, vivendo numa época em que apenas começava a colonização estrangeira, sob a forma de colônias agrícolas relativamente afastadas do conjunto da vida brasileira, não precisou imprimir ao seu nativismo o feitio duro e patético de batalha interior. Podia dar-lhe um aspecto mais natural, mais espontâneo. Quando, por conseguinte, se lhe censura a banalidade das descrições rápidas que insinuava por vezes, em traços ligeiros, entre as linhas da narrativa, esquece-se a reivindicação nativista que elas porventura encerram: o desejo de não cair no exotismo, porque o exotismo é ver o próprio país com olhos de estrangeiro - a vontade de exprimir o que vê o olho habituado à paisagem, o olho de um escritor que nunca saiu de sua terra, que não tem que fazer comparações, que grava o conjunto, e não o pitoresco de certos pormenores tropicais. E sempre a nota do dinamismo brasileiro civilizador, de que faz questão fechada: "Morro verde e crestado, palmeiras que recortais o céu azul, e tu, locomotiva do Corcovado que trazeis o sibilo da indústria humana ao concerto da natureza, bom dia!” (7).

Tais são, creio eu, as razões que levaram Machado a dissimular a paisagem na sua obra, a dissimulá-la por detrás dos homens. Não se deve, pois, falar de falta de sentimento da natureza ou de ausência de sensibilidade brasileira. Machado de Assis poderia, se 
quisesse, ter recheado a sua obra de descrições. Sua poesia no-lo prova. Com efeito, para bem conhecer um grande prosador, deve-se, quando possível, recorrer a seus versos. Por que a poesia de um prosador é como que o avesso de sua obra: revela o que ele teve de realçar para atingir a perfeição que se propôs conseguir. Charles Maurras di-lo excelentemente: queria escrever sob o signoda Razão, queria alhear completamente a sua política, do sentimento; mas nem por isso deixava de possuir uma sensibilidade cujas ondas turvas precisavam escoar-se fosse como fosse; e, como ele mesmo confessou, a poesia foi a libertação desse outro lado da sua personalidade. Há, portanto, oportunidades de descobrirmos nos volumes de poesias do nosso escritor o sentido da natureza e o gosto da descrição.

Deixemos de lado as Americanas, onde entretanto a descrição é tão desenvolvida que se torna fatigante, porque embora cantem os moradores das

\section{"[...] florestas}

Aonde habita o jaguar

Nas margens dos grandes rios

Que levam troncos ao mar",

trata-se sobretudo, nesses versos, de descrições históricas. Mas os outros livros estão cheios de paisagens, que provam como o poeta amava sua terra e lhe entendia a beleza saborosa e triunfal; assim, para só citar um exemplo, esta Manhã de Inverno, que tenta exprimir o que há de estranho numa manhã fria em pleno trópico:

"Vento frio, mas brando, agita as folhas Das laranjeiras úmidas da chuva;

Erma de flores, curva a planta o colo, E o chão recebe o pranto da viúva.

[...]

Galhardo moço, o inverno deste clima Na verde palma a sua história escreve".

Sabe-se que, na mocidade, consagrara ao Pão de Açúcar um extenso poema. Mas não gostava que lhe encomendassem paisagens. A anedota citada por Alfredo Pujol sobre o pedido de Ramos Paz para que o autor de $A$
Mão e a Luva ornasse seu romance com um parque, e a resposta de Machado de Assis, aquela descrição geométrica, seca, voluntariamente geométrica (só fala em separações, em caminhos que se cortam...), não têm, a meu ver, outra significação. Quando é seu coração que fala, então os termos lhe ocorrem facilmente: quando a Prefeitura carioca, com pruridos urbanísticos, demoliu a velha Rua Direita, o artista, comovido de ver desaparecer o pitoresco colonial escondido nesse bairro, tira de suas lembranças uma tocante evocação (8).

Mas não são apenas os versos que permitem conhecer um talento, mas também a crítica. Que qualidades exigia o escritor de seus contemporâneos? Qual o seu ideal de estilo? Fala freqüentemente de meias-tintas, de arte esfumaçada, da necessidade de ser sóbrio em literatura. E poderia por isso ser acusado de se haver forjado um ideal em contradição com a natureza tropical, violenta, rica, colorida, exuberante, com

8 A. Pujol, Machado de Assis, pp. 63 e 289

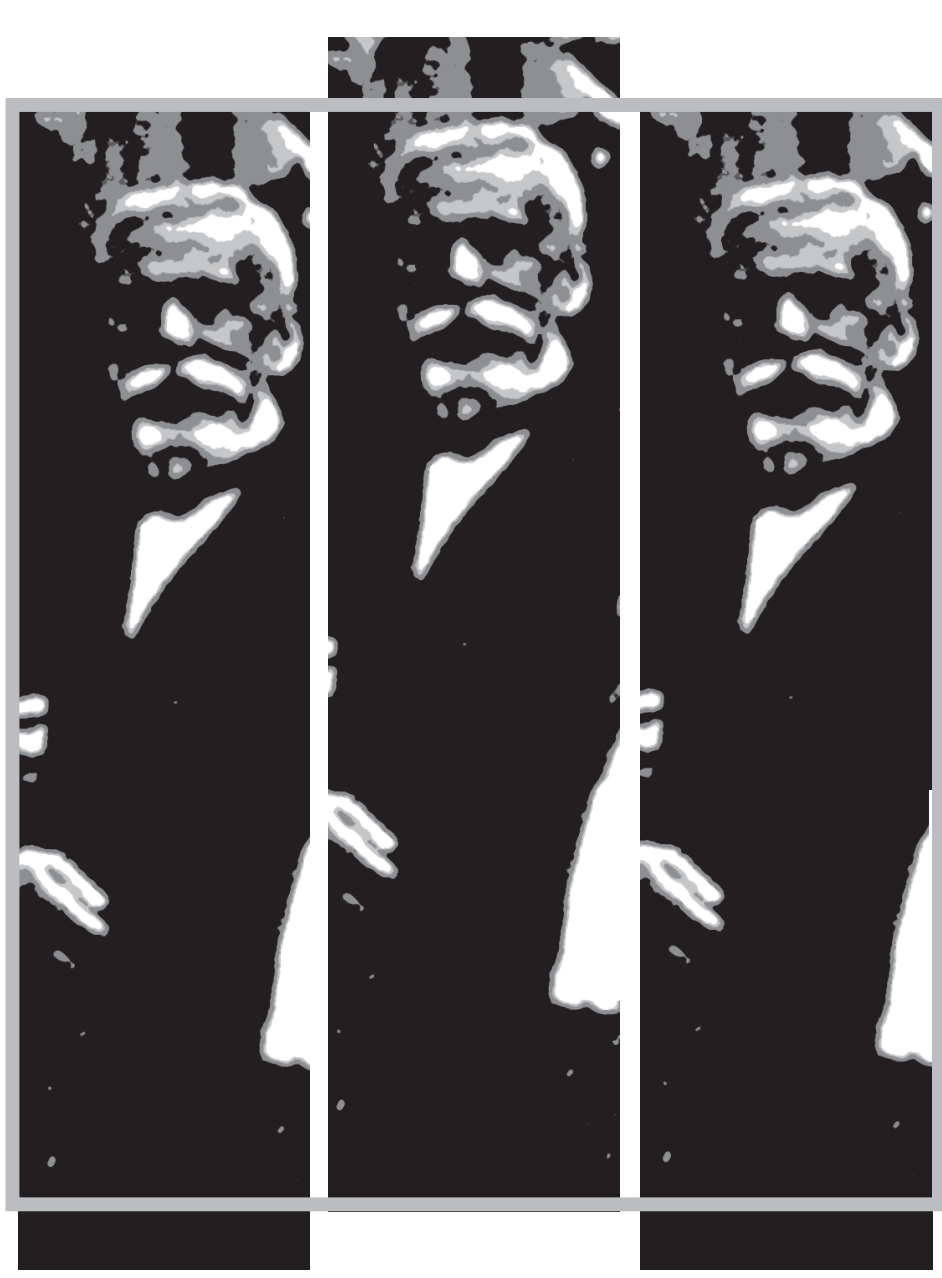


um país que ainda se acha, na expressão de Keyserling, no sétimo dia da criação. Certo, não nego a beleza do estilo tropical. Mas logo me detém esta frase de Machado: “É preciso não confundir o sentimento com o vocabulário". Assim como se podem exprimir sobriamente as tempestades do coração humano, como o fez Mérimée, não se poderia exprimir sem exuberância um clima tão vivo e ardente? E não será justamente isso que vamos descobrir na paisagem interiorizada do nosso autor?

Falando das Cenas da Vida Amazônica, de José Veríssimo, Machado de Assis elogia este último por ter sabido dar a sensação quase física da realidade vegetal e aquática do país. Mas acrescenta: "Não são descrições trazidas de acarreto" (9). E foi isso, com efeito, o que procurou realizar em seus romances: não permitir descrições para divertimento, verdadeiros enfeites postiços no livro; é preciso que a natureza seja uma personagem que represente o seu papel, que a paisagem tenha significação e finalidade próprias, que sirva para facilitar a compreensão dos homens ou auxiliar o desenrolar da ação, e não seja um mero quadro rígido. Problema difícil, ao qual, como veremos, deu, depois de um primeiro período de hesitações, a melhor solução possível.

Referindo-se, aliás, a Coelho Neto, Machado de Assis notou que ele possuía o sentido da paisagem, que empregava sempre as cores próprias, as palavras adequadas. Mas, ainda aqui, esse não é o seu maior elogio. O que lhe agrada nesse escritor é que a natureza está em toda a parte. Em toda a parte, isto é, mesmo onde não aparece à primeira vista, nos conflitos dos homens e no íntimo das almas. Texto particularmente revelador, pois que nos trai o segredo de Machado de Assis e nos indica a direção a tomar para descobrir a paisagem machadiana (10).

\section{||}

9 Crítica Literária, p. 250

10 A Semana.

11 Encyclopédie Française, 16 64-17.
Quando se estuda a evolução da pintura, vê-se que a paisagem foi de início apenas um fundo de quadro sobre o qual se destacava um retrato, uma cena mitológica ou religiosa. Há então dois casos a considerar: ou a natureza é uníssona com a cena, a doçura da atmosfera, o brilho torrencial da luz, o patético do crepúsculo correspondendo à doçura da parábola evangélica, à expressão apaixonada ou dramática dos personagens; ou, ao contrário, a paisagem contrasta com o assunto, ao qual, por essa oposição mesma, faz ressaltar.

Mais tarde, devia a natureza destacarse da pintura anedótica ou de retratos, para viver vida independente. Essa ruptura corresponde, no final das contas, à grande arrancada descritiva do romantismo literário. Apenas os maiores pintores guardaram a nostalgia de uma união cada vez mais estreita entre o homem e as coisas, de uma espécie de participação mística do humano com o telúrico. Mas, para realizar esse sonho, lançaram mão de múltiplos processos, de técnicas variadas.

O primeiro desses processos é o que Elie Faure chama a transposição dos elementos. Consiste em revestiros indivíduos das cores e nuanças da natureza que os cerca, em pôr o colorido das geleiras, as cintilações do mar, o castanho ou o ocre da terra natal sobre a pele e as roupas das personagens: "Para o pintor espanhol, a laranja do cesto do vendedor se reproduz no alaranjado dos crepúsculos de Castela, a neve da sierra nos vestidos das infantas. Para o pintor holandês, o irisado do arenque no balcão da peixaria de Amsterdã se encontra nos andrajos dos mendigos ou nas fontes de um rabino dos bairros pobres"(11). A natureza pode, pois, parecer ausente de uma tela, estando na realidade estranhamente presente, no homem vestido de água, de céu e de terra.

Mas essa tentativa de unificação só atinge a perfeição plena quando o pintor se recusa a representar unicamente

"a estrutura carnal superficial e seus estigmas sociais, deixando de inscrever nela o peso de sua relação total com o mundo exterior. Porque não é o caso de uma presença da paisagem conservando ainda uma aparência de exterioridade pelo fato mes- 
mo da separação do modelo e do meio onde vive, como se vê em certos retratos de grandes mestres italianos ou flamengos que reservam, ao lado da figura, um canto da tela para uma vista campestre de sua terra. Mas se quisermos ver nessa representação, não o desejo de colocar ao lado do ser vivo o quadro material em que evolve, mas, ao contrário, uma expressão simbólica da 'paisagem interior' do modelo, teremos que ao espectador cabe estabelecer a fusão entre os dois termos, e que um intervalo existirá sempre entre a personagem e a paisagem. Para que a fusão seja perfeita e a presença realmente absoluta é necessário que no retrato a paisagem se faça sentir como que virtualmente presente na própria arquitetura da face, na qualidade da luz - a grande unificadora, o meio universal - na escolha das cores, na sua transparência, na espessura da tinta" (12).

Foi exatamente esse o progresso que Cézanne imprimiu à pintura, como muito bem viu Eugenio d'Ors. Seus modelos, dizia este, trocam com a natureza ambiente "tantos sinais, tantas mensagens, tantas influências, realizam com ela tantos mútuos compromissos", que, "como as naturezas-mortas, esses retratos são, no fundo, paisagens". Pois bem, eu quereria demonstrar que foi um progresso do mesmo gênero que $\mathrm{Ma}$ chado de Assis imprimiu à literatura: a natureza, nele, não é ausente, mas ele soube suprimir o intervalo que a separava das personagens, misturando-a com estas, fazendo-a colar-se-lhes à carne e à sensibilidade, integrando-a na massa com que constrói os heróis de seus romances.

Certo, não chegou de golpe a essa mestria. No começo de sua carreira, deixa claros de paisagem, não enche a separação entre o homem e o mundo exterior; mas, como nas velhas escolas de pintura, esses rápidos panoramas, bosquejados com poucos traços de pena, têm por fim mostrar a analogia de sentimentos de seus heróis com a natureza, ou, ao contrário, seus contrastes. Esses dois temas são muito nítidos em Ressurreição, por exemplo, onde vemos no início o fervor de Félix, uníssono com o fervor das coisas, seu ardor participando do esplendor da luz, do jogo das nuvens e da magnificência do céu; enquanto o processo oposto foi utilizado no capítulo XIX (“A Porta do Céu”), em cujo curso a mudança de tempo segue a marcha inversa da evolução psicológica do herói: “Que lhe importava a ele a melancolia da natureza, se tinha dentro d'alma uma fonte de inefáveis alegrias?".

Abandonará, porém, felizmente, esses métodos sumários, e, como os pintores espanhóis e flamengos, operará a transposição dos elementos; vestirá suas personagens - sobretudo as femininas, mais permeáveis às influências telúricas ou climáticas, menos separadas do ambiente pelos artifícios sociais - das cores, das coisas, da luz do mundo exterior. A mulher não se isola da paisagem, mas aproveita-a, apropria-a, une-se-lhe, trá-la em si. Este trecho de Iaiá Garcia é sintomático do processo que Machado vai utilizar largamente: “A alma cobiçava um banho de azul e ouro e a tarde esperava-a trajada de suas púrpuras mais belas" (13). O que caracteriza a natureza carioca são a vegetação sensual, as voluptuosas noites quentes de verão, e sobretudo a presença do mar. Ora, esses três elementos são transpostos para se tornarem carne, sangue e vida, para integrar a arquitetura da face, para correr nas veias e bater docemente no pulso sob a delicadeza de uma pele feminina. As laranjeiras perfumadas das chácaras, os recantos de sombra úmida sob as árvores, a vida vegetal dos trópicos, que talvez não descreva, inscrevem-se no andar dessas mulheres-vegetais, dessas mulheres-paisagens. As noites do Rio se tornam cabeleiras, cabelos soltos, perfumados, mornos, voluptuosos, "cortados da capa da última noite". E se, na Europa, o poeta pode dizer que "Les yeux des femmes sont des Méditerranées", os olhos das heroínas de Machado de Assis, olhos verdes, olhos de ressaca, olhos de escuma com reflexos irisados, são feitos da própria cor do oceano que banha as praias do Brasil, guardando em suas vagas o encanto de Iemanjá, o apelo dos abismos, a carícia e a traição. Não se deve buscar alhu-
12 Roger Clement, "L'Humanisation du Paysage" in Cahiers du Sud, fevereiro de 1938

13 laiá Garcia, p. 239 
res a descrição da natureza brasileira; temola pintada por transposição, transparente através dessas mulheres vegetais e marítimas, que deixam no leitor um gosto de sal, de jardim adormecido ou de noite tépida.

Mas essas trocas constantes, essas mensagens sutis entre as coisas e os homens transcendem a natureza feminina para se alçarem por vezes a uma verdadeira lei cósmica: “As estrelas pareciam-lhe outras tantas notas musicais fixadas no céu à espera de alguém que as fosse descolar: tempo viria em que o céu tinha de ficar vazio, mas então a terra seria uma constelação de partituras" (14). Sim, é bem isso, Machado descola as estrelas, as palmas, a cor das águas e da terra, para pô-las nas faces, no desenho das mãos e no fundo dum sorriso.

Mais ainda, porém, do que para a transposição dos elementos, é para a paisagem interior que o nosso escritor apela para unir o homem e a natureza. O que nos obriga, para descobri-lo, a nos voltarmos "para dentro" (15), na sua expressão. À força de vivermos num certo meio, vão-se-nos impregnando dele os poros da pele, a carne, a própria personalidade de que passa a constituir parte integrante; por isso, tornada interior, a paisagem transparece-nos nos gestos, cobre-nos o rosto, canta-nos na voz ou brilha-nos nos olhos. Machado tinha disso experiência profunda; tornara-se o Rio: podia dizer, como um de seus heróis, que "as ruas faziam parte de minha pessoa" (16). E foi certamente dessa experiência que partiu para renovar a arte da paisagem, para descobrir um meio de fazer a beleza carioca servir mais intimamente à beleza de seus romances, de amplificar a música de suas frases com a música do oceano próximo. Seria muito longo citar todos os trechos que corroboram a minha idéia. Para me ater a Quincas Borba, Rubião não diz que traz sua terra natal "em si mesmo" (17), e Sofia, para ver melhor o mar, não fecha os olhos, porque ele batia-lhe nopulsoe as vagas lhe arrebentavam no coração? Sem dúvida, está na janela, mas se erguesse as pálpebras, a praia que veria não seria a verdadeira; a verdadeira praia, a sua, aquela na qual o barulho das ondas se confunde com o surdo ruído do coração, está dentro dela, e as águas a levam, sem vela nem remo (18).

Assim, sem a menor descrição, sem molduras, sem fundos de quadro, abolidas todas as distâncias, Machado de Assis realiza o milagre de tornar a natureza mais presente do que se a pintasse em longas páginas. Um de seus contos é absolutamente característico a esse respeito: “O Enfermeiro”. Sem nenhum pitoresco, sem digressões nem alusões ao meio, toda a oposição entre o litoral e o sertão mineiro se descobre na simples mudança dos gestos, na loucura sombria que sobe, numa espécie de surda angústia que terminará em crime. Este é, aliás, um tema caro ao autor: suas personagens vão encontrar a loucura, o desespero ou a destruição na solidão de Minas Gerais, cujo clima assim se exprime sem necessidade de fazer apelo à descrição do mundo exterior. Porque a natureza se confunde com o herói. Poderia citar também "Só", ritmado pela chuva interminável, a chuva dos trópicos, empapando o jardim da chácara, mas que também se infiltra pelas janelas, pelas paredes úmidas, pelos forros, pela carne, gotejando no coração, caindo sem trégua no cérebro, até transformar a alma de herói numa interminável chuva tropical (19).

Não é, porém, nos contos, mas nos romances que esse processo é utilizado com maior êxito. A natureza surge neles como uma realidade afetiva que se precisa descobrir nas entrelinhas, presente sob a forma da atmosfera que banha as pessoas, aureolalhes os gestos, transparece-lhes nas palavras. Não é, com efeito, impunemente que as casas dão para os jardins, não é impunemente que há em todos os seus romances uma janela aberta de par em par para a noite e para o mar. A noite e o mar entram nas salas, nos quartos, nas personagens que não se livram mais desse sortilégio. Já Machado tentara esse processo em A Mão e a Luva, onde o apaixonado se coloca entre a janela aberta e o mar, para que este some a sua beleza aos seus próprios sentimentos, de tal forma que o amor se torna uma atração da água (20). A mesma cena foi retomada, com muito maior mestria, em Quincas 
Borba. Sofia busca através das trevas a pálida luminosidade do mar de franja de espuma, procura nessa sombria ausência os sinais da voz do amado: "A noite estava clara. Fiquei quase uma hora entre o mar e sua casa. Quase ouvia a sua respiração. O mar batia com força, é verdade, mas meu coração não batia com menos intensidade". Romance urbano, romance psicológico, como quiserem, mas conheço poucos livros em que o ritmo do mar, a música das noites cariocas, a natureza brasileira, enfim, vivam de modo tão intenso, imponham a sua presença alucinatória, façam de tal modo corpo com a narrativa que esta se torne um drama noturno e marinho.

E o mar banha Dom Casmurro nas suas ondas salgadas, verdes e turvas; ondas que vêm morrer em cada linha, deixando sobre cada palavra flocos de espuma, canções noturnas. Nãoestá somente nos olhos de Capitu, esses olhos de cigana oblíqua e dissimulada:

"Traziam não sei que fluido misterioso e enérgico, uma força que arrastava para dentro, como a vaga que se retira da praia, nos dias de ressaca. Para não ser arrastado, agarrei-me às outras partes vizinhas, às orelhas, aos braços, aos cabelos espalhados pelos ombros; mas tão depressa buscava as pupilas, a onda que saía delas vinha crescendo, cava e escura, ameaçando envolver-me, puxar-me e tragar-me" (21),

mas liga ainda, com sua branca orla, suas linhas sinuosas, todas as partes do romance. Como o caminho das eglantinas do Coté de Chez Swan de Marcel Proust, o pedaço de praia entre a Glória e o Flamengo une com sua areia úmida, sua geografia oceânica e sentimental, a casa de Casmurro e a de Escobar; todos os acontecimentos do drama se situam em dois planos estreitamente misturados, doçura da luz na água e nos espíritos, tempestades nos corações e nas águas; constantemente é o olhar do leitor dirigido para as ondas furiosas ou acariciantes. A ligação é tão completa que o ciúme do herói só se precisa pouco a pouco, depois de se desviar, de hesitar entre o mar e o amigo (22); é o mar que se encar- regará da vingança, vingança ainda ignorada, palpitando ainda nas profundezas aquáticas do inconsciente: "o mar perverso", “o mar desencadeado", o que só restitui os cadáveres; são os olhos oceânicos que virão buscar o afogado, arrastá-lo, levá-lo para o palácio das lembranças como se fora ao mágico palácio das sereias: "Momento houve em que os olhos de Capitu fitaram o defunto, quais os da viúva, sem o pranto nem palavras desta, mas grandes e abertos, como a vaga do mar lá fora, como se quisessem tragar também o nadador da manhã" (23); todo o estilo de Machado de Assis torna-se marítimo:

“[...] os nossos temporais eram agora contínuos e terríveis. Antes de descoberta aquela má terra da verdade, tivemos outros de pouca dura; não tardava que o céu se fizesse azul, o sol claro e o mar chão, por onde abríamos novamente as velas que nos levavam às ilhas e costas mais belas do universo, até que outro pé de vento desbaratava tudo, e nós, postos à capa, esperávamos outra bonança, que não era tardia nem dúbia, antes total, próxima e firme.

\footnotetext{
21 Dom Casmurro, p. 104 22 Idem, caps. CVI e CVII. 23 Idem, p. 363
}

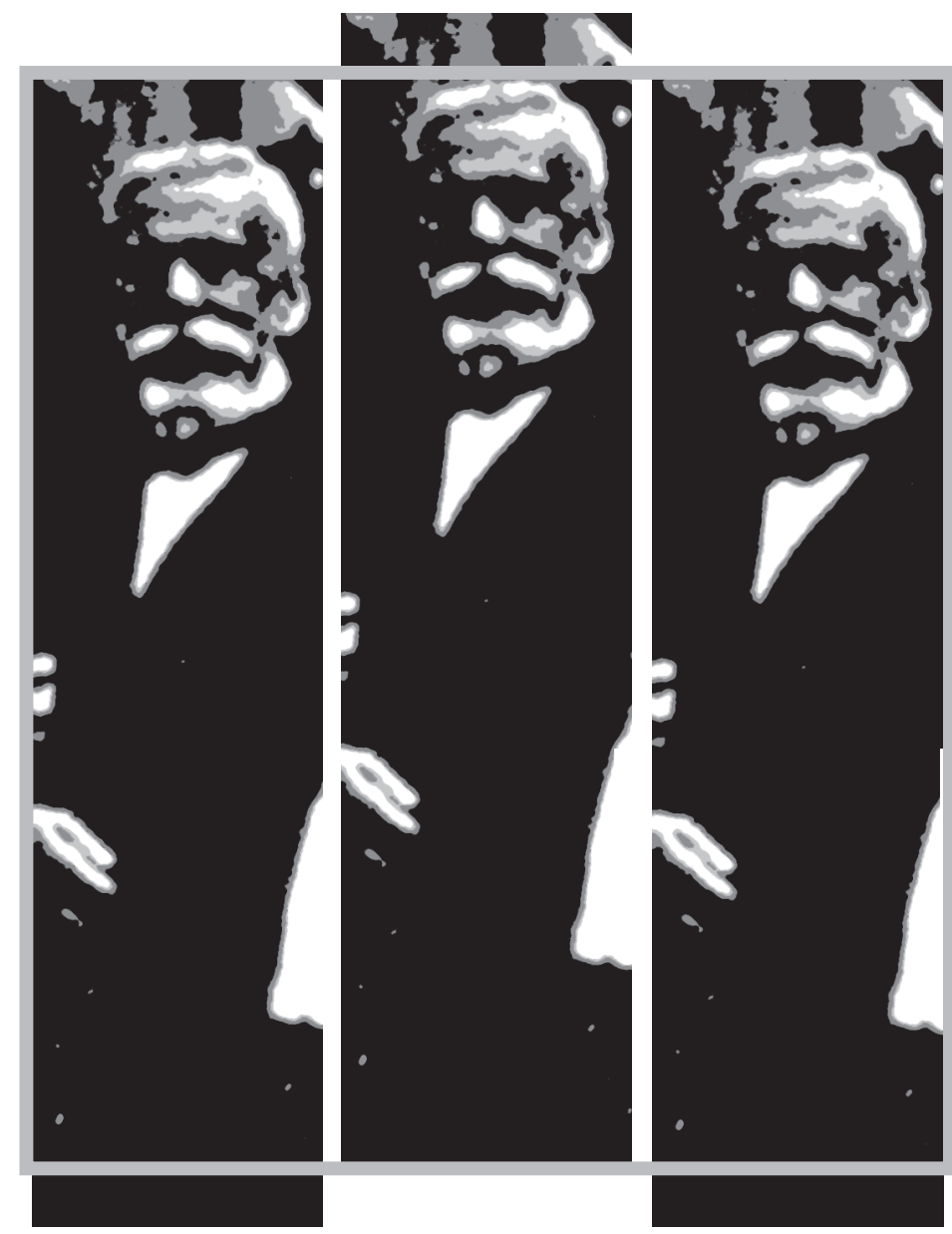


Releva-me estas metáforas; cheiram ao mar e à maré que deram morte ao meu amigo e comborço Escobar. Cheiram também aos olhos de ressaca de Capitu. Assim, posto sempre fosse homem de terra, conto aquela parte da minha vida, como um marujo contaria o seu naufrágio" (24).

Emcriança, Machado, interrogando oseu destino pela sorte da clara de ovo no copo d'água, via nos filamentos esbranquiçados a imagem dum navio partindo. E, embora homem de terra, sem aventuras, citadino agarrado às ruas cariocas, a predição se realizou. Como nas Naus Catarinetas do sertão, carregadas pelos homens sobre a terra dura e seca, como nas longínquas capelas do interior onde se balança, entre os ex-votos, uma caravela branca, o complexo brasileiro do mar, de que tão bem falou Mário de Andrade, habitava no coração desse homem imóvel, mas cercado pelas águas em pleno Rio, e seus livros, como o copo da infância, encerram em filamentos dispersos a imagem alucinatória do Atlântico.

Mas há em Dom Casmurro ainda outra presença, ou, melhor, a água, no livro, brinca com as plantas, canta nas chácaras, bate com suas vagas de sonho, como nos filmes em sobreimpressão, os jardins sombrios do centro da cidade. E não conheço nada mais tropical, mais brasileiro do que essa confusão de líquido e plantas, essas árvores que saem do mar, esses Amazonas correndo através de florestas, sem que se possa saber onde começa o rio e onde termina a floresta, esse sétimo dia da criação, em que ainda não terminou a separação entre águas e terras, em que não existe ainda linha divisória entre os elementos confundidos. Essa visão formidável, o autor no-la impõe sem uma só descrição, e todavia mais fortemente do que o conseguiria a mais rica das descrições; simplesmente, como depois fariam os filmes, misturou as duas realida- des, líquido e vegetal, a aroeira e a pitangueira aos rochedos batidos pelas ondas, $\mathrm{O}$ poço, a velha caçamba e o tanque a uma água mais amarga e salgada, as flores do velho jardim e a casa sobre o mar, e fez, enfim, da Capitu dos olhos de ressaca não somente uma mulher-marinha, mas também uma mulher- planta, porque a Capitu da Glória já existia na de Matacavalos: “se te lembras bem da Capitu menina, hás de reconhecer que uma estava dentro de outra, como a fruta dentro da casca" (25); e, assim, como o indicam os próprios termos de Machado, o crescimento da moça, essa sereia fugida das glaucas águas, torna-se um crescimento vegetal.

Seria possível mostrar no Memorial de Aires processos análogos; também aqui, sem recorrer às descrições, a principal personagem do romance é um jardim que não conhecemos, mas que não podemos esquecer, tanto o autor tornou real a sua presença em nós.

Coelho Neto contou esta impressão de uma leitora de Machado de Assis: "Sentese neste livro uma grande falta de ar...". Foi a impressão contrária que tive ao ler pela primeira vez Machado de Assis, a impressão de uma baforada de ar iodado e salgado em pleno rosto, da carícia de uma noite perfumada num jardim do Rio, da mais perfeita transcrição da essência da paisagem brasileira; e prefere-se sempre ao aroma que se dilui à força de descrições, cuja extensão e acumulação acabam esgotando o poder evocador, a rara essência da qual basta uma gota para perfumar todo o romance e fazer com que todas as palavras, ainda e sobretudo aquelas que nada dizem da natureza, trescalem a aroeira e pitangueira, a algas balançando-se nas praias, a brisa evolando-se do mar. E porque a impressão profunda que me deixou esse escritor foi a de ser um dos maiores paisagistas do Brasil, é que escrevi estas páginas de protesto contra os críticos literários que lhe negam essa qualidade: humilde homenagem de um estrangeiro a um mestre da literatura universal. 